\title{
STUDY ON THE CORROSIVE NATURE OF SOIL TOWARDS THE BURIED-STRUCTURES
}

\author{
Jagadeesh Bhattarai \\ Central Department of Chemistry, Tribhuvan University, Kathmandu.
}

\begin{abstract}
This work is focused to investigate soil parameters such as moisture content, $\mathrm{pH}$, resistivity, oxidationreduction potential, chloride and sulfate contents those affect the corrosive nature of soils toward the buried-galvanized steels and cast-iron pipelines used to supply the drinking water in Kathmandu Valley. It is found that the twenty three soil samples collected from the study areas are "mildly corrosive" to "non-corrosive" nature towards the buriedgalvanized steels and cast-iron pipes used to supply the drinking water in Kirtipur areas of Kathmandu Valley.
\end{abstract}

Keywords: Chloride content; Oxidation-reduction potential; Resistivity; Soil corrosivity; Sulfate content.

\section{INTRODUCTION}

Soils can be corrosive for the buried-structures like galvanized-steels and iron-cast pipelines used to supply the drinking water from reservoirs to consumers. Mitigating measures taken into account during design and construction while the effects of corrosive soil can cause structural failure of the buried-structural materials. An understanding of the corrosivity of a particular soil can minimize such soil corrosion of the buried-structural materials. The study of the soil corrosion of buried-structural materials is importance, because millions of miles of the buried steels or ironpipelines are used to supply the drinking water, gas, oil and so on in the world. Corrosion control of these buried-structural materials necessitates a huge amount of money for regular maintenance and replacement. The corrosion rate of the buried-structural materials is mainly influenced by six different soil parameters like moisture content, $\mathrm{pH}$, resistivity, oxidation-reduction potential, chloride and sulfate contents ${ }^{1-3}$. Estimation of such soil parameters can give an indication of the soil corrosivity towards the buried-structural materials like galvanized steel and cast-iron pipes.

Numerous studies on soil corrosion on the buriedstructures have carried out ${ }^{4-19}$. It has been reported that the corrosion behaviour of galvanized steels and bare steels after exposure for thirteen years in different soils of USA by Danison and Romanoff in early of $1950 \mathrm{~s}^{4,5}$. It was reported that the corrosion of mild steel increased when soil moisture content exceeds $40 \%$ and suggested that the maximum corrosion rates occur at saturations of $60-85 \%{ }^{4}$. Soil resistivity has the largest effect on the observed maximum average pitting corrosion rate on the surface of the buried-pipelines ${ }^{6}$. Many buriedstructural materials, such as galvanized water supply pipelines, natural gas and crude oil pipelines have been corroded by soils all around the world ${ }^{4-7,10,13,16,18}$. It has been reported that the aggressiveness of soil towards the drinking water supply pipeline used in Toronto city of Canada was affected by soil properties such as resistivity, $\mathrm{pH}$ and the presence of sulfate-reducing bacteria ${ }^{10}$. Study on Nigeria pipeline of crude oil (along the Obrikom-Ebocha areas) showed that the soil resistivity value decreased with increasing the moisture content and temperature ${ }^{13}$. It has been reported that the sandy and gravel soils have a high resistivity (more than $6000 \mathrm{ohm} . \mathrm{cm}$ ) and therefore, considered to be "mildly corrosive" or "excellent corrosion resistance" for the galvanized steels and cast-iron pipes, while a clayey soil with a resistivity less than $1000 \mathrm{ohm} . \mathrm{cm}$ is generally considered to be "highly corrosive" for the buriedgalvanized steels ${ }^{1-3}$. Soils having high resistivity (i.e., low conductivity) are generally least corrosive for the buried-structural materials.

It has been reported that soil is generally considered "mildly corrosive" if the sulfate and chloride in soils are below $200 \mathrm{ppm}$ and $100 \mathrm{ppm}$, respectively, with $\mathrm{pH}$ of 5-9 and the resistivity greater than 5,000 ohm. $\mathrm{cm}^{1-3,8,9}$. The presence of sulfate more than $200 \mathrm{ppm}$ in soils can pose a major risk for the buried-structural materials $^{8-11}$, because it can readily be converted to highly corrosive sulfides by anaerobic sulfate-reducing bacteria. Maslehuddin et al. (2007) studied the effect of chloride concentration in soil on the corrosion behavior of reinforcing steels ${ }^{15}$.

The of city supply water is mostly through the buried galvanized steels and cast-iron pipelines in

Author for correspondence: Jagadeesh Bhattarai Central Department of Chemistry, Tribhuvan University, Kathmandu, Nepal. E-mail: bhattarai_05@yahoo.com. 
Kathmandu Valley. For the purpose of security and safety all such water supply pipelines are generally buried beneath the earth surface to a depth of about 1 meter. The repeated failure as a result of corrosion of the buried water supply pipelines in Kathmandu Valley is observed for a long time. In this context, it is very urgent to investigate the effects of different soil parameters that affect the corrosive nature of soils on the buriedgalvanized steel and cast-iron pipelines used to supply the city water in Kathmandu Valley.

The main objectives of this study are to know the effect of soil parameters on the corrosivity of such buried-structural materials and to specify the corrosive nature of soils of Panga-Kirtipur-Tyanglaphant areas of Kirtipur Municipality.

\section{EXPERIMENTAL METHODS}

Twenty three soil samples were collected from PangaKirtipur-Tyanglaphant areas of Kitipur Municipality. The Panga-Kirtipur-Tyanglaphant area is located within the latitude of $27^{\circ} 40^{\prime} 05^{\prime \prime}-27^{\circ} 41^{\prime} 30^{\prime \prime} \mathrm{N}$ and within the longitude of $85^{\circ} 16^{\prime} 10^{\prime \prime}-85^{\circ} 17^{\prime} 10^{\prime \prime} \mathrm{E}$ as shown in Fig. 1. All soil samples were taken from the depth of about 1 meter from the ground level for the real location of the buried-pipelines for the purpose of the supply of drinking water. The distance between two samples was taken about 300 to 500 meters. The soil sample was taken in an air tight polyvinyl bag so that the moisture remained same for a period of moisture content analysis in the laboratory.

Moisture content in soil was determined using weight loss method in accordance with the ASTM D4959-07 standards $^{20}$. A digital $\mathrm{pH}$ meter was used to determine the $\mathrm{pH}$ of 1:2 soil-water suspension of each soil samples in accordance with the ASTM G51-95 (2012) standards ${ }^{21}$. The conductivity bridge was used to determine the electrical conductivity of the 1:2 soil-water suspension in accordance with the ASTM G187-05 standards ${ }^{22}$. The soil resistivity (bulk/saturated paste) was calculated from the conductivity. The oxidation-reduction potential (ORP) of the soil samples was measured with the help of a digital potentiometer in accordance with the ASTM G200-09 standards ${ }^{23}$. The platinum wire and saturated calomel electrodes (SHE) were used as working and reference electrode, respectively. The recorded ORP values vs SCE was converted to reference value of the saturated hydrogen electrode (SHE). Argentometric titration was used to determine the amount of chloride content in soil. Chloride content in the 1:2 soil-water suspension was determined by titrating the soil suspension against standard silver nitrate solution using potassium chromate as an indicator. Gravimetric method was used to estimate the amounts of sulfate content in soil samples. The details of these all methods are discussed in elsewhere ${ }^{24,25}$.
Fig. 1: Location map of the Panga-Kirtipur-Tyanglaphant sampling sites of Kirtipur Municipality of Kathmandu district.

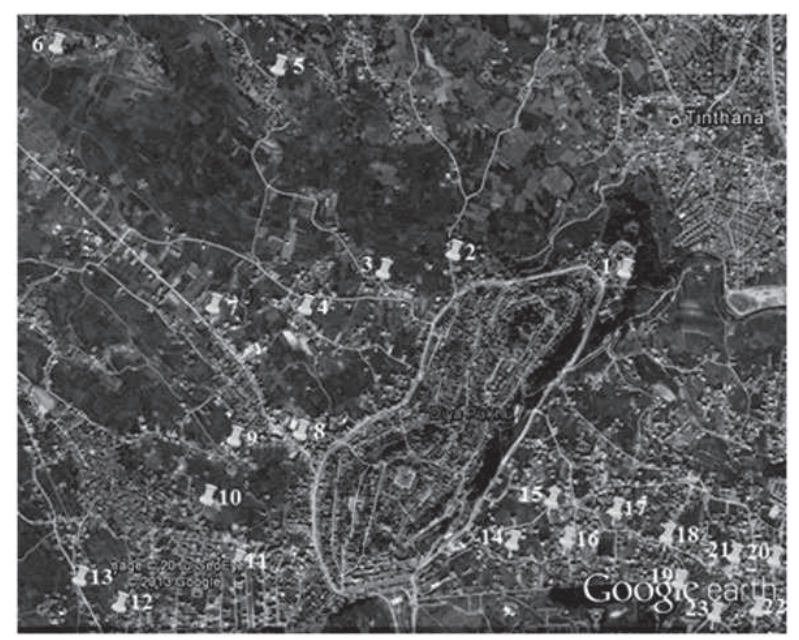

RESULTS AND DISCUSSION

\section{Moisture content in soil}

The moisture content in soil is one of the most important parameters of soil corrosion towards the buried-structural materials. The moisture content in the collected soil samples was in the range of 15 to $48 \%$. Among these twenty three soil samples, five samples have less than $20 \%$, while sixteen samples have $20-40 \%$ and only two samples have more than $40 \%$ moisture content (Table 1). It is considered that the soil samples holding less than $40 \%$ moisture content are probably due to the mixture of sand and clay or sandy soils. These results revealed that all the soil samples are assumed to be "mildly corrosive" to "non corrosive" towards the buried-galvanized steels and cast-iron pipelines.

\section{Soil pH}

All twenty three soil samples collected from the study area are neutral or slightly alkaline in nature showing the $\mathrm{pH}$ values in the range of 6.4-7.9 as presented in Table 1. Among these twenty three soil samples, fifteen are neutral (6.4-7.4) and eight are slightly alkaline (7.57.9) in nature. Therefore, all twenty three soil samples analyzed in this research work are assumed to be "mildly corrosive" to "non-corrosive" nature towards the galvanized steels and cast-iron pipelines.

\section{Soil resistivity}

The soil resistivity (saturated paste resistivity) is actual "bulk resistivity" of soil influences by types of soil, moisture content, concentration of different dissolved salts, degree of compactness and temperature so on. Since the soil resistivity was not measured in the sampling sites, all these affecting factors except types, moisture content and dissolved salts are changed from their in-situ values. Hence, in this research work, all efforts were made to insure uniformity among the resistivity tests performed in the laboratory. All soil samples were tested at room temperature at $25^{\circ} \mathrm{C}$ 
Table 1: Soil parameters of Panga-Kirtipur-Tyanglaphant areas of Kirtipur Municipality.

\begin{tabular}{|c|c|c|c|c|c|c|c|}
\hline S.N. & $\begin{array}{l}\text { Sample } \\
\text { Name }\end{array}$ & $\begin{array}{l}\text { Moisture } \\
\text { Content (\%) }\end{array}$ & Soil $p H$ & $\begin{array}{l}\text { Soil Resistivity } \\
\text { (ohm.cm) }\end{array}$ & $\begin{array}{c}\text { ORP } \\
(m V v S S C E)\end{array}$ & $\begin{array}{l}\text { Chloride } \\
\text { (ppm) }\end{array}$ & $\begin{array}{l}\text { Sulphate } \\
\text { (ppm) }\end{array}$ \\
\hline 1 & PKT1 & 25 & 6.4 & 45,500 & 514 & 21 & 65 \\
\hline 2 & PKT2 & 32 & 7.4 & 10,100 & 424 & 50 & 171 \\
\hline 3 & РKT3 & 32 & 6.9 & 11,600 & 341 & 27 & 74 \\
\hline 4 & PKT4 & 36 & 6.9 & 15,900 & 441 & 23 & 86 \\
\hline 5 & PKT5 & 29 & 6.7 & 43,500 & 400 & 23 & 50 \\
\hline 6 & PKT6 & 21 & 7.1 & 62,500 & 439 & 16 & 41 \\
\hline 7 & PKT7 & 35 & 7.6 & 25,000 & 442 & 30 & 64 \\
\hline 8 & PKT8 & 30 & 7.6 & 13,900 & 425 & 30 & 124 \\
\hline 9 & PKT9 & 34 & 7.4 & 5,000 & 441 & 68 & 138 \\
\hline 1 & 0РKT10 & 32 & 7.1 & 25,600 & 392 & 16 & 77 \\
\hline 11 & PKT11 & 36 & 7.0 & 23,300 & 401 & 24 & 65 \\
\hline 12 & PKT12 & 46 & 6.9 & 6,100 & 332 & 56 & 273 \\
\hline 13 & PKT13 & 48 & 7.1 & 3,300 & 446 & 90 & 143 \\
\hline 14 & PKT14 & 20 & 7.6 & 20,800 & 383 & 35 & 110 \\
\hline 15 & PKT15 & 17 & 7.7 & 17,900 & 385 & 33 & 110 \\
\hline 16 & PKT16 & 15 & 7.8 & 18,500 & 441 & 47 & 82 \\
\hline 17 & PKT17 & 19 & 7.6 & 23,800 & 307 & 68 & 67 \\
\hline 18 & PKT18 & 18 & 7.5 & 26,300 & 395 & 38 & 82 \\
\hline 19 & PKT19 & 16 & 7.9 & 20,800 & 418 & 42 & 102 \\
\hline 20 & РKT20 & 30 & 7.2 & 10,200 & 342 & 55 & 192 \\
\hline 21 & PKT21 & 32 & 7.2 & 10,400 & 361 & 52 & 165 \\
\hline 22 & PKT22 & 24 & 7.1 & 13,200 & 344 & 64 & 137 \\
\hline 23 & PKT23 & 30 & 7.1 & 10,000 & 331 & 67 & 137 \\
\hline
\end{tabular}

which was remained constant and an effort was made to compact the soils to the same degree into the square soil box.

Table 1 shows the soil resistivity value of all twenty three soil samples collected from study areas. Only one sample has less than $5,000 \mathrm{ohm} . \mathrm{cm}$ soil resistivity, two have 5,000-10,000 ohm.cm, ten have 10,000-20,000 ohm.cm, seven have 20,000-30,000 ohm.cm and three soil samples have above $40,000 \mathrm{ohm}$.cm soil resistivity among these twenty three soil samples. These results revealed that most of the soil samples collected from the study areas are "mildly corrosive" to "essentially non-corrosive" in nature for the buried-structural materials based on the $\mathrm{ASTM}^{9}$ and $\mathrm{NACE}^{26}$ standards. It is meaningful to mention here that the soil corrosivity towards the buried-structural materials was classified into six groups (i.e., essentially non-corrosive, mildly corrosive, moderately corrosive, corrosive, highly corrosive and extremely corrosive) as shown in Table $2^{8,9,26}$.

\section{Oxidation-reduction potential of soil}

The measurement of the oxidation-reduction potential (ORP) of soils is significant to explain the soil corrosivity towards the buried-structural materials, because it determines partially the stability of the materials. In general, an anaerobic soils having low ORP less than about $100 \mathrm{mV}$ vs SHE are not helpful for formation of passive oxide layers on the surface of the materials, because the anaerobic soils do not contain any free oxygen which is necessary for the passivation of the buried-iron/steels ${ }^{33}$. Furthermore, the ORP of a soil indicates whether or not a soil is capable of sustaining 
sulfate-reducing bacteria (SRB), which contribute greatly to the corrosion problem. A low ORP indicates that oxygen content in the soil is low. Consequently, the condition is ideal for the proliferation of the sulfatereducing bacteria, the greater the sulfide content in soils by reducing sulfate to sulfide. This is possible only the ORP is less than zero or negative values ${ }^{26}$.

The ORP value of all twenty three soil samples collected from the study areas is higher than $300 \mathrm{mV}$ vs SHE as presented in Table 1. Among these twenty three soil samples, twelve samples have ORP values in the ranges of 300-400 $\mathrm{mV}$ vs SHE, ten samples have 401$500 \mathrm{mV}$ vs SHE and only of soil sample has more than $500 \mathrm{mV}$ vs SHE ORP. These results revealed that all soil samples collected from the study areas of Kirtipur are belonged to "mildly corrosive" to "non corrosive" for the buried-structural materials based on the Johes' classification (as given in Table 3$)^{27}$.

\section{Chloride content in soil}

The contribution of chloride ions to soil corrosivity towards the buried-materials is very significant, because it also participates directly in pit initiation on the surface of stainless steels. Chloride ion is not only promoting the pitting corrosion of stainless steels, but it also inhibits the passivity of the buried-structural materials. In addition, the presence of chloride content tends to decrease soil resistivity ${ }^{1}$.

The chloride content in all twenty three soil samples collected from the present study areas is found to be below $100 \mathrm{ppm}$. Among these twenty three soil samples, fourteen soil samples have less than $50 \mathrm{ppm}$ of chloride content, while eleven samples have between 50-100 ppm chloride content as presented in Table 1 . These results revealed that soils of Panga-Kirtipur-Tyanglaphant areas are considered to be "mildly corrosive" to "noncorrosive" towards the galvanized steels and cast-iron pipelines used to supply the drinking water in the areas, because the soils containing less than $50 \mathrm{ppm}$ chloride content and more than $10,000 \mathrm{ohm} . \mathrm{cm}$ soils resistivity are categorized "non-corrosive" soils towards the buried-structural materials ${ }^{8,9,26}$.

\section{Sulfate content in soil}

Sulfate content in soil is generally harmful for the buried-structural materials, as it participates directly in the electrochemical reactions that take place during corrosion process. It participates directly in pit initiation of stainless steels and also increases the soil conductivity. The soil containing less than $200 \mathrm{ppm}$ of sulfate is considered as "mildly corrosive" $8,9,26$. Sulfate content in all twenty three soil samples collected from Panga-Kirtipur-Tyanglaphant area is found to be less than 200 ppm except one soil sample (that is, PKT12) as presented in Table 1. These results revealed that all most all soil samples of Panga-Kirtipur-Tyanglaphant area of Kathmandu Valley are considered to be "mildly corrosive" to "non-corrosive" towards the galvanized steels and cast-iron pipelines.

Table 2: Relationship between soil resistivity, chloride and sulphate content and soil corrosivity towards the buriedstructural material ${ }^{8,9,26}$.

Soil Parameter Soil Corrosivity Rate

1. Soil Resistivity (ohm.cm)

$\begin{array}{cl}>20,000 & \text { Essentially non-corrosive } \\ 10,000-20,000 & \text { Mildly corrosive } \\ 5,000-10,000 & \text { Moderately corrosive } \\ 3,000-5,000 & \text { Corrosive } \\ 1,000-3,000 & \text { Highly corrosive } \\ <1,000 & \text { Extremely corrosive }\end{array}$

2. Chloride Content (ppm)

$$
<100 \quad \text { Mildly corrosive }
$$

3.Sulphate Content (ppm)

$$
<200
$$

Mildly corrosive

Table 3: Rating of soil corrosivity based on the oxidationreduction potential of soils ${ }^{27}$.

\begin{tabular}{cl}
\hline $\begin{array}{l}\text { Oxidation-reduction } \\
\text { Potential (mV vs SHE) }\end{array}$ & \multicolumn{1}{c}{ Soil Corrosivity } \\
\hline$>400$ & Non-corrosive \\
$201-400$ & Mildly corrosive \\
$100-200$ & Moderately corrosive \\
$<100$ & Severe corrosive \\
\hline
\end{tabular}

\section{CONCLUSIONS:}

Twenty three soil samples from Panga-KirtipurTyanglaphant area of Kathmandu district were collected to investigate the soil corrosivity towards the buriedgalvanized steels and cast-iron pipes used to supply the drinking water in the study areas. Following conclusions are drawn from the above results and discussion.

1. Most of the collected soils from Panga-KirtipurTyanglaphant area are sandy or mixture of sand and clay which are assumed to be "mildly corrosive" to "non-corrosive" towards the galvanized steels and cast-iron pipes used to supply the city drinking water.

2. Most of the soils of the study areas are nearly neutral to slightly alkaline which is in the range of "mildly corrosive" to "non-corrosive" for the underground galvanized steels and cast-iron pipelines.

3. Based on the soil resistivity, it is found that all the soil samples collected from Panga-KirtipurTyanglaphant area are categorized to "mildly corrosive" or "essentially non-corrosive" towards the buried-galvanized steels and cast-iron pipelines.

4. All the soil samples collected from Panga-KirtipurTyanglaphant area of Kathmandu Valley have the oxidation-reduction potential value in the range 
of $300-512 \mathrm{mV}$ vs SHE, which support the fact that these soils are "mildly corrosive" or "noncorrosive" towards the buried-galvanized steels and cast-iron pipelines.

5. The chloride content in all twenty three soil samples are within the upper limits (i.e., less than 100 ppm) for the corrosivity of soils towards the buriedstructural materials.

6. Sulfate content in twenty two soil samples (except one soil sample) is within the upper limits of 200 ppm for "mildly corrosive" towards the buriedgalvanized steels and cast-iron pipelines.

7. It can be advised to the related authorities or local people that simple modification of the soils by using cheapest non-conducting materials like gravel or sand around the buried water supply galvanized and cast-iron pipelines is necessary before undergrounding them in the study areas of Kathmandu Valley to increase the life time of the pipelines.

\section{AKNOWLEDGEMENT}

Author would like to acknowledge to Nepal Academy of Science and Technology (NAST) for providing the NAST research grant-2067 (Grant No.:536-067/068) to conduct this research work in Central department of Chemistry, Tribhuvan University, Kirtipur, and also to Mr. Madhav Gautam and Mr. Jhalak Narayan Timilsena for their effort to conduct the soil analyses in CDC.

\section{REFERENCES}

1. Uhlig, H. H. and Revie, R. W. 1991. in Corrosion and Corrosion Control; an Introduction to Corrosion Science and Engineering, $3^{\text {rd }}$ edition, John Wiley and Sons, New York.

2. Bhattarai, J. 2010. Frontiers of Corrosion Science. $1^{\text {st }}$ edition, Kshitiz Publ., Kirtipur, Kathmandu.

3. Bhattarai, J. 2010. Spectrum; an Annual Science Magazine of ChemSA, Central Department of Chemistry, Tribhuvan University, Kirtipur. 15:9-14.

4. Denison, I. A. and Romanoff, M. 1952. Journal of Research of the National Bureau of Standards. 49(5):299-316.

5. Romanoff, M. 1957. in Underground Corrosion, Circ. 579, US National Bureau of Standards.

6. Schashle, E. and Marsh, G. A. 1963. Materials Protection. 2:8-17.

7. Levlin, E. 1992. in Corrosion of Water Pipe Systems due to Acidification of Soil and Groundwater. Research Report, Department of Applied Electrochemistry and Corrosion Science, Royal Institute of Technology, Stockholm.

8. Robinson, W. 1993. Materials Performance. 32(4):56-58.

9. Escalante, E. 1995. in Soils, Corrosion Test and Standards, ASTM.

10. Doyle, G. 2000. The Role of Soil in the External Corrosion of Cast Iron Water Mains in Toronto, Canada. MS thesis, Graduate Department of Civil Engineering, University of Toronto, Canada. pp:75.

11. Bayliss, D. A. and Deacon, H. 2002. Steelwork Corrosion
Control, $2^{\text {nd }}$ edition, Spon Press, London.

12. Doyle, G., Seica, M. V. and Grabinsky, M. W. F. 2003. Canadian Geotechnology Journal. 40:225-236.

13. Rim-rukehand, A. and Awalefe, J. K. 2006. Journal of Applied Science Research. 2 (8):466-469.

14. Li, S. Y., Jung, S. and Park, K. 2007. Journal of Materials Chemistry and Physics. 103: 9-13.

15. Maslehuddin, M., Al-Zahrani, M. M., Ibrahim, M., AlMethel, M. H. and Al-Idi, S. H. 2007. Journal of Construction and Building Material. 21:1825-1832.

16. Alhazzaa, M. I. 2007. A Comparative Study of Soil Corrosivity of the University Campus. Final Research Report No. 45/426, King Saud University College of Engineering Research Center. pp:27.

17. Ismail, A. I. and El-Shamy, A. M. 2009. Journal of Applied Clay Science. 42: 356-362.

18. Shamsuri, S. R. B. 2010. The Effect of Soil Resistivity on Corrosion Behavior of Coated and Uncoated Low Carbon Steel. ME Thesis, Faculty of Mechanical Engineering, University Teknologi Malaysia.

19. Norhazilan, M. N., Nordin, Y., Lim, K. S., Siti, R. O., Safuan, A. R. A. and Norhamimi, M. H. 2012. Journal of Applied Science Research. 8 (3): 1739-1747.

20. ASTM D4959-07. 2007. "Standard Test Method for Determination of Water (Moisture) Content of Soil by Direct Heating". Annual Book of ASTM Standards, American Society for Testing Materials.

21. ASTM G51-95(2021). 2012. "Standard Test Method for Measurement of pH of Soil for Use in Corrosion Testing”. Annual Book of ASTM Standards, American Society for Testing Materials.

22. ASTM G187-05. 2005. "Standard Test Method for Measurement of Soil Resistivity Using Two-electrode Soil Box Method". Annual Book of ASTM Standards, American Society for Testing Materials.

23. ASTM G200-09. 2009. "Standard Test Method for Measurement of Oxidation-Reduction Potential (ORP) of Soil". Annual Book of ASTM Standards, American Society for Testing Materials.

24. Gautam, M. 2012. Investigation on Different Soil Parameters of Tanglaphant-Tribhuvan University Campus-Balkhu Areas of Kirtipur for Their Corrosive Nature, M.Sc. Dissertation, Central Department of Chemistry, Tribhuvan University, Kathmandu. pp:62.

25. Bhattarai, J. 2013. Investigation of Soil Parameters for Their Corrosivity on Buried Galvanized Steel Pipelines Used in Kathmandu Valley, Research report, submitted to Nepal Academy of Science and Technology (NAST), Khumaltar, Lalitpur. pp:42.

26. NACE 1993. Underground Corrosion, National Association of Corrosion Engineering (NACE) Publications, the Corrosion/93 Symposium.

27. Jones, D. A. 1996. in Principles and Prevention of Corrosion, $2^{\text {nd }}$ edition, Prentice Hall. 